\title{
STUDI KINETIKA REAKSI ESTERIFIKASI ENZIMATIS ASAM MIRISTAT DENGAN OLEIL ALKOHOL
}

\author{
Emmy Yuanita*, Erin Ryantin Gunawan, Lely kurniawati, Siti Raudhatul Kamali \\ ${ }^{a}$ Department of Chemistry, University of Mataram \\ Jl. Majapahit 62 Mataram 83125 \\ Tel/Fax : 0370-634708; \\ e-mail: my_yuanita@yahoo.co.id
}

\begin{abstract}
ABSTRAK
Studi kinetika reaksi esterifikasi enzimatis asam miristat dan oleil alkohol telah dilakukan. Penelitian ini bertujuan untuk mendapatkan hasil sintesis yang optimal, sehingga meningkatkan konversi dan kecepatan reaksi pembentukan wax ester. Analisis kualitatif wax ester yang terbentuk dilakukan secara TLC dan GC, sedangkan analisis secara kuantitatif dilakukan secara titrasi asam-basa. Dari hasil penelitian diperoleh $\%$ konversi wax ester dengan menggunakan enzim tanpa perlakuan sebesar 94,44\%. Nilai $\mathrm{Km}$ dan Vmax untuk asam miristat sebesar 2,5649 dan 14,3823 mmol x10-5 mmol/menit.mg katalis sedangkan untuk oleil alkohol sebesar 7,0345 dan 29,2292 mmol x10-mmol/menit.mg katalis. Sehingga dapat disimpulkan bahwa kinetika reaksi esterifikasi asam miristat dengan oleil Alkohol yang dikatalisis oleh enzim lipase tanpa perlakuan mengikuti Model Michaelis-Menten sedangkan mekanisme reaksi esterifikasi mengikuti mekanisme Bi Bi Ping-Pong
\end{abstract}

Keywords: Km, Vmaks, asam miristat, wax ester

\section{KINETICS STUDY OF ENZYMATIC ESTERIFICATION REACTION OF MYRISTIC ACID WITH OLEYL ALCOHOL}

\begin{abstract}
Study of the kinetics of enzymatic esterification of myristic acid and oleyl alcohol has been investigated. This research aims to obtain an optimum synthesis, thus increasing the conversion and reaction speed wax ester formation. In this research wax esters formed were analyzed by TLC and GC qualitatively and quantitatively with the acid-base titration. The results obtained \% wax ester conversion using enzymes without treatment by $94.44 \%$. $\mathrm{Km}$ and Vmax values for myristic acid at 2.5649 and $14.3823 \mathrm{mmol} \mathrm{x} 10-5 \mathrm{mmol} /$ menit.mg catalyst for oleyl alcohol while at 7.0345 and $29.2292 \mathrm{mmol} x 10$ $\mathrm{mmol} /$ menit.mg catalyst. It can be concluded that the kinetics of esterification of myristic acid with oleyl alcohol catalyzed by the enzyme lipase without treatment followed Michaelis-Menten model, while the mechanism of the esterification reaction follows the mechanism of Bi Bi Ping-Pong
\end{abstract}

Keywords: Km, Vmaks, myristic acid, wax ester 


\section{PENDAHULUAN}

Kasus produk kosmetik berbahaya seperti lotion, krem, bedak, lipstik serta berbagai jenis kosmetik lain yang beredar di pasaran menimbulkan keresahan di kalangan masyarakat. Bahaya kosmetik ini disebabkan penggunaan bahan dasar serta bahan tambahan tersebut berasal dari bahan yang sangat berbahaya bagi kesehatan walaupun bahan berbahaya tersebut dalam kosmetik sekecil mungkin (tidak lebih dari $10 \%$ ), tetapi pemakaian secara terus menerus akan mengakibatkan toksik pada kulit, seperti iritasi pada kulit dan bahkan dapat menyebabkan kanker.

Untuk meminimalisasi berbagai penyakit yang ditimbulkan oleh kosmetika yang mengandung bahan berbahaya, seperti asam retinoat, hidrokuinon dan lain sebagainya maka perlu dilakukan pencarian bahan dasar kosmetik serta bahan tambahan yang tidak membahayakan kesehatan konsumen, salah satunya dengan menggunakan ester asam lemak. Senyawa ester asam lemak berperan sebagai emollient dan emulsifier dalam produk lotion, cream, dan kosmetik sejenisnya (Hilyati, dkk., 2003). Salah satu ester asam lemak berupa wax ester. Wax ester dapat diperoleh dari hasil esterifikasi asam lemak dan alkohol rantai panjang (Chen and Wang, 1997; Hallberg, dkk., 1999)

Sintesis wax ester ini dapat dilakukan secara kimiawi dan secara enzimatis, namun sintesis secara kimiawi memiliki banyak kekurangan seperti dapat menyebabkan korosi peralatan, bahaya dalam penanganan asam korosif, biaya produksi mahal karena membutuhkan energi yang besar dan degradasi ester. Sedangkan sintesis enzimatik menawarkan kondisi reaksi yang ringan dan ramah lingkungan (Gunawan dan Suhendra, 2008).
Penelitian tentang sintesis wax ester dari asam miristat dan oleat dengan oleil alkohol secara enzimatis mulai banyak dilakukan, antara lain oleh Rahmatullaili (2011) yang menghasilkan kondisi optimum untuk sintesis wax ester dari asam lemak oleat adalah pada perbandingan molar asam lemak oleat dan oleil 1:2, dengan jumlah enzim lipase 0,1 gram, pada suhu $40{ }^{\circ} \mathrm{C}$, selama 5 jam dan dengan n-heksan sebagai pelarut terbaik. Persentase konversi wax ester yang diperoleh pada kondisi optimum adalah sebesar 97,59\% (Rahmatullaili, 2011). Sedangkan sintesis wax ester dari asam miristat diperoleh pada suhu $40{ }^{\circ} \mathrm{C}$ selama 2 jam dengan jumlah katalis enzim 0,15 gram dan perbandingan asam miristat: oleil adalah 1:3 dengan pelarut n-heksan. Persentase wax ester yang diperoleh pada kondisi optimum ini adalah 97,50 \% (Ruslin, 2011).

\section{METODE PENELITIAN}

\section{Bahan dan Alat}

Bahan-bahan yang digunakan dalam penelitian ini adalah asam miristat $98 \%$, oleil alkohol $85 \%, \mathrm{NaOH}$, asam oksalat anhidrat, indikator fenolftalein (PP), TLC dan bahan-bahan berderajat pro analysis seperti dietil eter, n-heksan, ester standar (metil palmitat), dan enzim lipase. Peralatan yang digunakan dalam penelitian ini adalah seperangkat alat gelas, timbangan analitik Ohaus Galaxy 400 (USA), penangas air, oven, water shaker bath Julabo SW23 (Germany), Gas Chromatography (GC) dan buret.

\section{Prosedur Penelitian}

Prosedur penelitian sintesis wax ester dari asam lemak miristat dengan oleil alkohol ini dilakukan secara enzimatis dengan beberapa tahap pengerjaan meliputi tahap persiapan 
enzim, sintesis wax ester (reaksi esterifikasi), penentuan pengaruh konsentrasi enzim terhadap kecepatan awal reaksi esterifikasi, penentuan pengaruh konsentrasi substrat terhadap kecepatan awal reaksi esterifikasi, analisis wax ester dan analisis data. Adapun prosedur selengkapnya adalah sebagai berikut:

\section{Tahap Persiapan Enzim}

Pada tahap persiapan enzim untuk proses esterifikasi ini dilakukan melalui 3 perlakuan, yaitu enzim tanpa perlakuan, enzim dipanaskan, dan enzim diinkubasi.

\section{a. Enzim tanpa perlakuan}

Sebanyak 0,15 gram enzim lipase yang digunakan untuk reaksi esterifikasi tidak diperlakukan sebelum digunakan untuk esterifikasi.

\section{b. Enzim yang dipanaskan}

Sebanyak 0,15 gram enzim lipase dipanaskan pada suhu $40 \quad{ }^{\circ} \mathrm{C}$ selama 4 jam sebelum digunakan untuk reaksi esterifikasi.

\section{c. Enzim yang diinkubasi}

Sebanyak 0,15 gram enzim lipase diinkubasi dalam n-heksan pada suhu $40{ }^{\circ} \mathrm{C}$ selama 4 jam sebelum digunakan untuk reaksi esterifikasi.

\section{Tahap Sintesis Wax ester (Reaksi Esterifikasi)}

Sintesis wax ester dari asam miristat dilakukan melalui reaksi esterifikasi dengan mereaksikan $1 \mathrm{mmol}$ asam miristat dan $1 \mathrm{mmol}$ oleil alkohol dengan bantuan enzim lipase 0,15 gram sebagai katalis ke dalam Erlenmeyer. Kemudian ditambahkan $2 \mathrm{~mL}$ n-heksan. Campuran ini kemudian diinkubasi dalam waterbath shaker dengan variasi waktu 5 menit, 60 menit, 120 menit, 180 menit, 240 menit, 300 menit dan 360 menit. pada suhu $40{ }^{\circ} \mathrm{C}$. Setelah wax ester terbentuk, reaksi dihentikan dengan memisahkan enzim lipase dari wax ester dengan cara difiltrasi.

Sintesis wax ester dari asam oleat perlakuannya sama seperti pada sintesis wax ester dari asam miristat, tetapi jumlah enzim dan variasi waktu yang digunakan berbeda. Jumlah enzim yang digunakan 0,1 gram dan variasi waktunya adalah 0 jam; 0,5 jam; 1 jam; 2 jam; 3 jam; 4 jam; 5 jam dan 6 jam.

\section{Penentuan Pengaruh Kondisi Konsentrasi Enzim terhadap Kecepatan Awal Reaksi Esterifikasi}

Kondisi reaksi: $1 \mathrm{mmol}$ asam miristat, $1 \mathrm{mmol}$ oleil alkohol, $2 \mathrm{~mL} \mathrm{n-}$ heksan dan variasi konsentrasi dari enzim lipase ( 0 gram, 0,05 gram, dan 0,2 gram). Campuran reaksi diinkubasi pada suhu $40{ }^{\circ} \mathrm{C}$ dengan waktu inkubasi optimum yang diperoleh pada tahap sintesis wax ester. Kondisi reaksi untuk asam olet sama seperti pada asam miristat.

\section{Penentuan Pengaruh Konsentrasi Substrat terhadap Kecepatan Awal Reaksi Esterifikasi Asam Miristat dengan Oleil Alkohol}

Kondisi reaksi: variasi asam miristat (0,5 mmol, $1 \mathrm{mmol}, 1,5 \mathrm{mmol}, 2$ mmol, 2,5 mmol, $3 \mathrm{mmol}, 3,5 \mathrm{mmol}$ dan $4 \mathrm{mmol}$ ) direaksikan dengan $1 \mathrm{mmol}$ oleil alkohol, $2 \mathrm{~mL}$ n-heksan dan dengan sejumlah enzim lipase optimum. Campuran reaksi diinkubasi pada suhu $40{ }^{\circ} \mathrm{C}$, dengan waktu inkubasi optimum yang diperoleh pada tahap sintesis wax ester. Perlakuan diulangi dengan konsentrasi oleil alkohol $2 \mathrm{mmol}$ dan 3 mmol.

Kondisi reaksi: variasi oleil alkohol (0,5 mmol, $1 \mathrm{mmol}, 1,5 \mathrm{mmol}, 2$ mmol, 2,5 mmol, $3 \mathrm{mmol}, 3,5 \mathrm{mmol}$ dan 
4 mmol) direaksikan dengan $1 \mathrm{mmol}$ asam miristat, $2 \mathrm{~mL}$ n-heksan dan dengan sejumlah enzim lipase optimum. Campuran reaksi diinkubasi pada suhu $40{ }^{\circ} \mathrm{C}$, dengan waktu inkubasi optimum yang diperoleh pada tahap sintesis wax ester.

Perlakuan diulangi dengan konsentrasi asam miristat $2 \mathrm{mmol}$ dan 3 mmol.

\section{Tahap Analisis Wax Ester}

\section{a. Analisis kualitatif dengan KLT dan GC}

Analisa kualitatif wax ester dari asam miristat dan oleil alkohol secara enzimatis ini dilakukan dengan menggunakan kromatografi lapis tipis (KLT) dan GC. Wax ester dilarutkan dalam n-heksan kemudian ditotolkan pada plat KLT, dielusikan pada sistem pelarut n-heksan : etil asetat : asam asetat (8:2:1). Spot yang terbentuk divisualisasikan dengan uap iodin yang akan membentuk spot berwarna coklat. Hasil elusi sampel dibandingkan nilai Rf -nya dengan standar. Untuk analisa GC menggunakan kolom Rtx65 TG, dimana suhu awal kolom $150{ }^{\circ} \mathrm{C}$ diatur konstan selama 2 menit, kemudian temperatur dinaikan $20{ }^{\circ} \mathrm{C} /$ menit sampai temperatur akhir $300{ }^{\circ} \mathrm{C}$ dan dibiarkan konstan selama 10 menit. Suhu akhir kolom adalah lebih dari $300{ }^{\circ} \mathrm{C}$.

\section{b. Analisis kuantitatif dengan titrasi asam-basa}

Analisis kadar wax ester hasil sintesis dari asam lemak oleat dan oleil alkohol secara enzimatis ini dilakukan dengan metode titrasi asam-basa untuk mengetahui jumlah asam lemak oleat yang tidak bereaksi. Wax ester yang terbentuk ditambahkan beberapa tetes indikator PP kemudian dititrasi dengan menggunakan $\mathrm{NaOH}$ 0,01 M. Dilakukan 3 kali pengulangan.
Dari hasil titrasi asam-basa ini kita dapat menentukan persentase konversi wax ester hasil sintesis dari asam lemak miristat dan oleil alkohol secara enzimatis. Dengan perlakuan yang sama juga dilakukan pada wax ester yang diperoleh dari asam oleat dengan oleil alkohol secara enzimatis.

\section{Tahap Analisis Data}

\section{a. Analisis kualitatif dan kuantitatif dan Wax Ester}

Analisis kualitatif wax ester diakukan dengan KLT Analisis dengan KLT dilakukan untuk memisahkan komponen-komponen pada sampel dengan menghitung nilai Rfnya. Nilai Rf ditentukan dengan menggunakan persamaan di bawah ini

$$
R f=\frac{\text { jarak yang ditempuh sampel }}{\text { jarak yang ditempuheluen }}
$$

Analisis kuantitatif wax ester menggunakan metode titrasi. Dari hasil titrasi diketahui volume $\mathrm{NaOH}$ yang bereaksi dengan wax ester pada titik akhir titrasi. Persentase hasil konversi wax ester digunakan persamaan berikut:

$\%$ Konversi=

$\mathrm{VNaOH}$ (tanpa enzim) - $\mathrm{VNaOH}$ (dengan enzim) $\times 100 \%$

$\mathrm{V} \mathrm{NaOH}$ tanpa enzim

\section{b. Analisis data kinetika}

\section{Penentuan Kecepatan Awal pada Reaksi Esterifikasi serta Penentuan Konsentrasi Enzim}

Kecepatan awal diperoleh dari slope yang dialurkan dari grafik hubungan antara konversi wax ester yang terbentuk dengan waktu, dan satuannya adalah mmol. $\min ^{-1} \cdot \mathrm{mg}^{-1}$. 
Studi Kinetika Reaksi Esterifikasi Enzimatis... (Emmy Yuanita, dkk.)

$\mathrm{V}_{0}=\frac{\text { mmol wax ester }}{\text { waktu inkubasi }(\text { menit })}$

\section{Perhitungan Konsentrasi Enzim}

Konsentrasi enzim $=\frac{m g \text { enzim }}{V \text { pelarut }}$

\section{Persamaan Michaels-Menten}

Dibuat grafik hubungan antara kecepatan awal dengan konsentrasi asam lemak (dimana konsentrasi enzim yang digunakan adalah tetap). Begitupun dengan substrat oleil alkohol, dibuat grafik hubungan antara kecepatan awal dengan konsentrasi oleil alkohol.

3. Penentuan nilai $K_{\text {maks }}$ dan $V_{\text {maks }}$

Penentuan $\mathrm{K}_{\text {maks }}$ dan $\mathrm{V}_{\text {maks }}$ dilakukan dengan membuat grafik Lineweaver-Burk.

Dengan persamaan regresi linier

$$
\mathrm{Y}=\mathrm{aX}+\mathrm{b}
$$

Dimana:

$$
\begin{aligned}
& \mathrm{Km}=-\mathrm{b} / \mathrm{a} \\
& \mathrm{Vmaks}=1 / \mathrm{b}
\end{aligned}
$$

\section{HASIL DAN PEMBAHASAN}

Wax ester merupakan ester rantai panjang yang diperoleh dari asam lemak dan alkohol rantai panjang dengan jumlah karbon 12 atau lebih. Pada penelitian ini sintesis wax ester dilakukan melalui reaksi esterifikasi enzimatis dengan mereaksikan asam miristat dengan oleil alkohol serta katalis enzim lipase dalam pelarut n-heksan. Pemilihan n-heksan sebagai pelarut berdasarkan sifat n-heksan yang merupakan pelarut non polar yang memiliki peubah air yang lemah sehingga kemampuannya untuk mengubah konformasi aktif enzim juga semakin lemah. n-heksan merupakan pelarut terbaik untuk reaksi yang dikatalisis oleh lipase (Gunawan dan Suhendra, 2008). Mengacu pada penelitian sebelumnya bahwa pelarut nheksan memberikan \% konversi tertinggi dari pelarut lainnya. Sintesis awal dilakukan dengan menggunakan ketiga enzim pada tahap persiapan enzim.

Hasil sintesis wax ester dari asam miristat dengan oleil alkohol terbentuk filtrat berwarna bening kekuningkuningan. Dimana hasil sintesis kemudian dianalisa dengan KLT sehingga diperoleh data Rf dan gambar kromatogram sebagai berikut

Tabel 1. Data Nilai Rf dari 3 perlakukan terhadap enzim

\begin{tabular}{|c|c|c|c|}
\hline \multirow{2}{*}{$\begin{array}{c}\text { Noda } \\
\text { Spot }\end{array}$} & \multicolumn{3}{|c|}{ Rf } \\
\cline { 2 - 4 } & $\mathrm{A}$ & $\mathrm{B}$ & $\mathrm{C}$ \\
\hline $\mathrm{AM}$ & 0,4 & 0,08 & 0 \\
\hline $\mathrm{OA}$ & 0,48 & 0,42 & 0,65 \\
\hline $\mathrm{Es}, \mathrm{st}$ & 0,93 & 0,78 & 0,98 \\
\hline $\mathrm{WE}_{1}$ & 0,35 & 0,33 & 0,63 \\
\hline $\mathrm{WE}_{2}(\mathrm{a})$ & 0,25 & 0,17 & 0,42 \\
\hline $\mathrm{WE}_{2}$ (b) & 0,88 & 0,92 & 0,98 \\
\hline
\end{tabular}

Keterangan :

(A) tanpa perlakukan awal enzim

(B) enzim dengan pemanasan

(C) enzim diinkubasi

$\mathrm{AM}=$ asam miristat, $\mathrm{OA}=$ oleil alkohol,

$\mathrm{Es}, \mathrm{St}=$ ester standar, $\mathrm{WE}_{1}=$ wax ester tanpa enzim (setelah diinkubasi)

$\mathrm{WE}_{2}=$ wax ester dengan enzim (setelah diinkubasi)
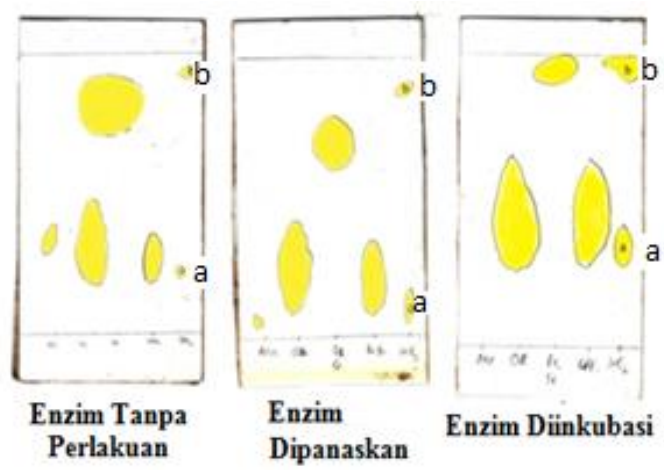
Gambar 1. Kromatogram Hasil Sintesis Wax ester

Dari data nilai Rf dan gambar kromatogram hasil sintesis wax ester menggunakan enzim tanpa perlakuan, dipanaskan, dan diinkubasi, tampak pada spot $\mathrm{WE}_{2}$ masing-masing terbentuk dua spot. Spot $\mathrm{WE}_{2}$ (a) diidentifikasi sebagai asam miristat dan oleil alkohol yang belum terpisahkan, karena nilai Rf-nya berada diantara nilai $\mathrm{Rf}$ asam miristat dan oleil alkohol. Pada komatogram tampak bahwa spot asam miristat muncul terlebih dahulu, hal ini karena karena senyawa asam miristat dapat membentuk ikatan hidrogen yang lebih kuat daripada ketiga senyawa lainnya, sehingga terjerap lebih kuat pada fase diam.

Berdasarkan data nilai $\mathrm{Rf}$ dan kromatogram dari ketiga perlakuan enzim sintesis dilanjutkan dengan menggunakan enzim tanpa perlakuan hal ini karena nilai $\mathrm{Rf}$-nya sudah mendekati nilai Rf wax ester standar

Untuk hasil analisa dengan GC diperoleh kromatogram sebagai berikut:

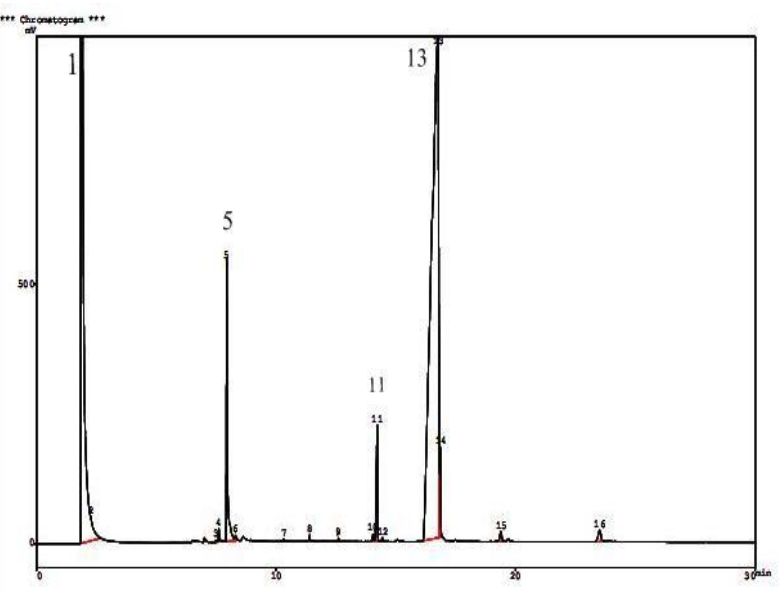

Gambar 2. Kromatogram GC dari wax ester hasil reaksi esterifikasi asam miristat dan oleil alkohol

Dari 16 puncak di atas, diperkirakan ada 4 puncak utama (puncak 1, 5, 11, dan 13) dan 12 puncak lainnya kemungkinan merupakan pengotor. Pada kromatogram puncak 1 diperkirakan sebagai pelarut n-heksan dengan titik didih $68,9{ }^{\circ} \mathrm{C}$. Puncak 5 diperkirakan sebagai oleil alkohol dengan waktu retensi 7,609 menit dengan titik didih $330-360{ }^{\circ} \mathrm{C}$. Puncak 11 diperkirakan sebagai asam miristat dengan waktu retensi 14,219 menit dengan titik didih $250{ }^{\circ} \mathrm{C}$. Puncak 13 diperkirakan sebagai oleil miristat dengan waktu retensi 16,756 menit. Walaupun oleil alkohol memiliki titik didih yang lebih tinggi dari asam miristat, namun pada kromatogram tampak bahwa oleil alkohol muncul terlebih dahulu daripada asam miristat, hal ini kemungkinan karena asam miristat memiliki kelarutan yang lebih tinggi dalam fase cair daripada oleil alkohol. Waktu retensi juga dipengaruhi oleh kelarutan senyawa dalam fase cair. Senyawa yang memiliki kelarutan yang tinggi dalam fase cair akan memiliki waktu retensi yang lama.

Sehingga dari analisis kualitatif baik menggunakan KLT maupun GC diperoleh bahwa hasil sintesis merupakan wax ester oleil miristat.

Analisis kuantitatif wax ester yang terbentuk dilakukan dengan menggunakan titrasi asam basa untuk menentukan kadar atau \% konversinya. Titrasi merupakan suatu metode untuk menentukan kadar suatu zat dengan menggunakan zat lain yang sudah diketahui konsentrasinya. Titrasi asam basa merupakan titrasi yang melibatkan asam dan basa (Morie, 2008). Titrasi asam basa dapat memberikan titik akhir yang cukup tajam, titik akhir akan tajam juga pada titrasi asam basa lemah jika titernya adalah asam atau basa kuat dengan perbandingan tetapan disosiasi asam lebih besar dari $10^{4}$ (Khopkar, 2008).

Pada penelitian ini titer yang digunakan adalah $\mathrm{NaOH} \quad 0,01 \quad \mathrm{M}$. 
Sebelum digunakan untuk titrasi wax ester, larutan $\mathrm{NaOH}$ terlebih dahulu distandarisasi dengan cara mentitrasi $\mathrm{NaOH} 0,01 \mathrm{M}$ dengan asam oksalat 0,01 N. Sedikit demi sedekit asam oksalat direaksikan dengan $5 \mathrm{~mL} \mathrm{NaOH} \mathrm{0,01} \mathrm{M.}$ Untuk mengetahui titik akhir titrasi, pada titran ditambahkan 2 atau 3 tetes indikator sebelum dititrasi. Titik akhir atau titik ekivalen dari titrasi dapat ditandai dengan perubahan warna, pada saat titik ekivalen inilah titrasi dihentikan. Pemilihan indikator yang digunakan harus tepat dan sesuai dengan yang dititrasi.

Pada penelitian ini digunakan indikator asam-basa yaitu indikator pp. Titik akhir titrasi pada standarisasi $\mathrm{NaOH}$ 0,01 ditandai perubahan warna dari merah muda menjadi bening, dengan volume 2,3 $\mathrm{mL}$ sehingga diketahui konsentrasi $\mathrm{NaOH}$ adalah $0,0092 \quad \mathrm{~N} \sim 0,01 \quad \mathrm{~N}$. Tujuan dari standarisasi ini adalah untuk memastikan apakah konsentrasi larutan $\mathrm{NaOH}$ yang kita buat sudah sesuai dengan konsentrasi yang diinginkan.

Hasil yang diperoleh dengan menggunakan ketiga enzim lipase pada tahap persiapan enzim memberikan hasil konversi yang sama seperti yang disajikan Tabel 2. Sehingga dapat disimpulkan bahwa untuk sintesis lebih lanjut dapat digunakan enzim tanpa perlakuan untuk menghemat energi dan biaya selain dari data nilai $\mathrm{Rf}$ dan kromatogram menunjukkan hasil yang sama.

Tabel 2. Persentase konversi oleil miristat

\begin{tabular}{|c|c|c|c|}
\hline \multirow{2}{*}{$\begin{array}{l}\text { Perlakuan } \\
\text { Enzim }\end{array}$} & \multicolumn{2}{|c|}{ Volume $\mathrm{NaOH}(\mathrm{mL})$} & \multirow{2}{*}{$\begin{array}{l}\% \text { Kon- } \\
\text { versi }\end{array}$} \\
\hline & $\begin{array}{l}\text { Tanpa } \\
\text { Enzim }\end{array}$ & $\begin{array}{c}\text { Dengan } \\
\text { Enzim }\end{array}$ & \\
\hline $\begin{array}{l}\text { Enzim } \\
\text { Tanpa } \\
\text { Perlakuan }\end{array}$ & 1,8 & 0,1 & $94,44 \%$ \\
\hline $\begin{array}{l}\text { Enzim } \\
\text { dipanaskan }\end{array}$ & 1,8 & 0,1 & $94,44 \%$ \\
\hline
\end{tabular}

\begin{tabular}{|l|c|c|c|}
\hline $\begin{array}{l}\text { Enzim } \\
\text { diinkubasi }\end{array}$ & 1,8 & 0,1 & $94,44 \%$ \\
\hline
\end{tabular}

\section{Penentuan Nilai Km dan Vmaks}

\section{Pengaruh konsentrasi enzim terhadap kecepatan awal reaksi}

Salah satu faktor yang mempengaruhi kecepatan reaksi pada katalis pada umumnya, adalah konsentrasi enzim (Poedjiadi dan Supriyanti, 2007). Pengaruh konsentrasi enzim lipase terhadap kecepatan pembentukan oleil miristat disajikan dalam tabel berikut ini

Tabel 3. Persentase wax ester (oleil miristat) untuk penentuan pengaruh konsentrasi enzim terhadap kecepatan awal reaksi

\begin{tabular}{|c|c|c|c|}
\hline \multirow{2}{*}{$\begin{array}{l}\text { Jum- } \\
\text { lah } \\
\text { enzim } \\
\text { (gram) }\end{array}$} & \multicolumn{2}{|c|}{$\begin{array}{l}\mathrm{V}_{\mathrm{NaOH}} \text { hasil } \\
\text { titrasi }\end{array}$} & \multirow{2}{*}{$\begin{array}{c}\text { \% kon- } \\
\text { versi }\end{array}$} \\
\hline & $\begin{array}{l}\text { Tanpa } \\
\text { enzim }\end{array}$ & $\begin{array}{c}\text { Dengan } \\
\text { enzim }\end{array}$ & \\
\hline 0,05 & 4,8 & 0,2 & $95,83 \%$ \\
\hline 0,1 & 4,8 & 0,2 & $95,83 \%$ \\
\hline 0,15 & 4,8 & 0,15 & $96,87 \%$ \\
\hline 0,2 & 4,8 & 0,15 & $96,87 \%$ \\
\hline 0,25 & 4,8 & 0,15 & $96,87 \%$ \\
\hline 0,3 & 4,8 & 0,15 & $96,87 \%$ \\
\hline
\end{tabular}

Berdasarkan nilai persentase konversi kemudian ditentukan nilai Vo serta konentrasi enzim berdasrakan rumus sehingga diperoleh data seperti Tabel 4 dan grafik ditunjukkan Gambar 3.

Tabel 4. Nilai $\mathrm{V}_{0}$ untuk penentuan pengaruh konsentrasi enzim terhadap kecepatan awal reaksi esterifikasi

\begin{tabular}{|c|c|}
\hline $\begin{array}{c}\text { Konsentrasi } \\
\text { enzim }(\mathrm{mg} / \mathrm{mL})\end{array}$ & $\begin{array}{c}\mathrm{V}_{0} \\
(\mathrm{mmol} / \text { menit })\end{array}$ \\
\hline 25 & $8 \times 10^{-3}$ \\
\hline 50 & $8 \times 10^{-3}$ \\
\hline 75 & $8.0725 \times 10^{-3}$ \\
\hline 100 & $8.0725 \times 10^{-3}$ \\
\hline
\end{tabular}




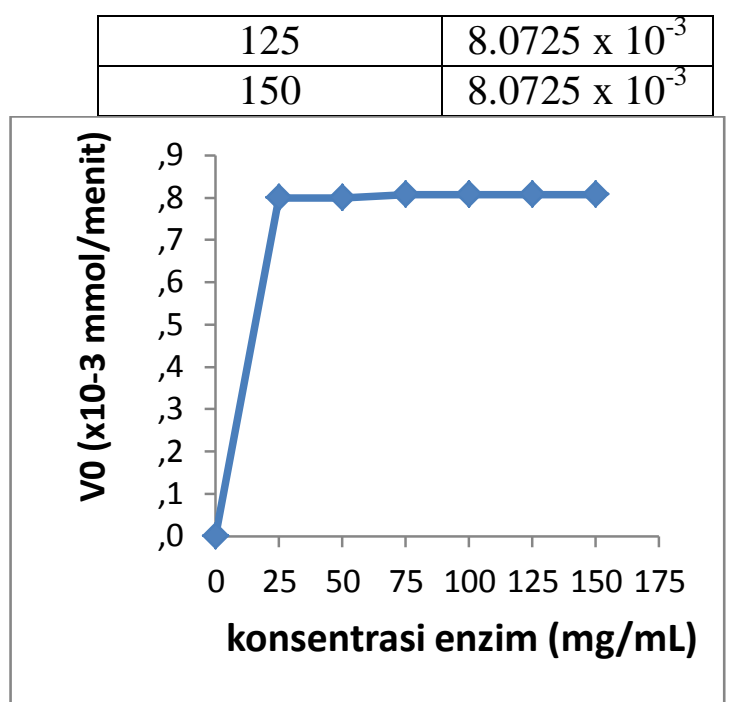

Gambar 3. Pengaruh konsentrasi enzim terhadap kecepatan awal reaksi pembentukan oleil miristat

Pada grafik Gambar 3. diperoleh bahwa pada konsetrasi $25 \mathrm{mg} / \mathrm{mL}$ mulai menunjukkan kecepatan pembentukan oleil miristat yang linear. Sebenarnya pada peningkatan konsentrasi $75 \mathrm{mg} / \mathrm{mL}$ terjadi peningkatan kecepatan reaksi pembentukan oleil alkohol, tetapi peningkatan ini sangat kecil dari $7,9858 \times 10^{-3} \mathrm{mmol} /$ menit menjadi 8,0725 $\mathrm{mmol} / \mathrm{menit}$. Sehingga grafiknya tampak linear dari konsentrasi enzim $25 \mathrm{mg} / \mathrm{mL}$.

\section{Pengaruh Konsentrasi Substrat terhadap Kecepatan Awal Reaksi Esterifikasi}

Konsentrasi substrat sangat berpengaruh terhadap kecepatan reaksi enzim. Pada konsentrasi yang rendah, kecepatan reaksipun rendah dan kecepatan reaksi akan meningkat dengan bertambahnya konsentrasi substrat, hingga dicapai titik batas yang disebut Vmaks. Apabila telah melampaui titik ini peningkatan konsentrasi substrat tidak akan meningkatkan kecepatan reaksi, karena pada keadaan ini enzim dikatakan "jenuh" oleh substrat.
Kinetika reaksi yang diamati pada pengaruh konsentrasi dari asam miristat dan oleil alkohol tehadap kecepatan awal reaksi esterifikasi pembentukan oleil miristat secara enzimatis menunjukkan kurva hiperbolik yang mengindikasikan bahwa enzim lipase mengikuti kinetika MichaelisMenten, seperti yang tampak pada Gambar 4 dan Gambar 5.

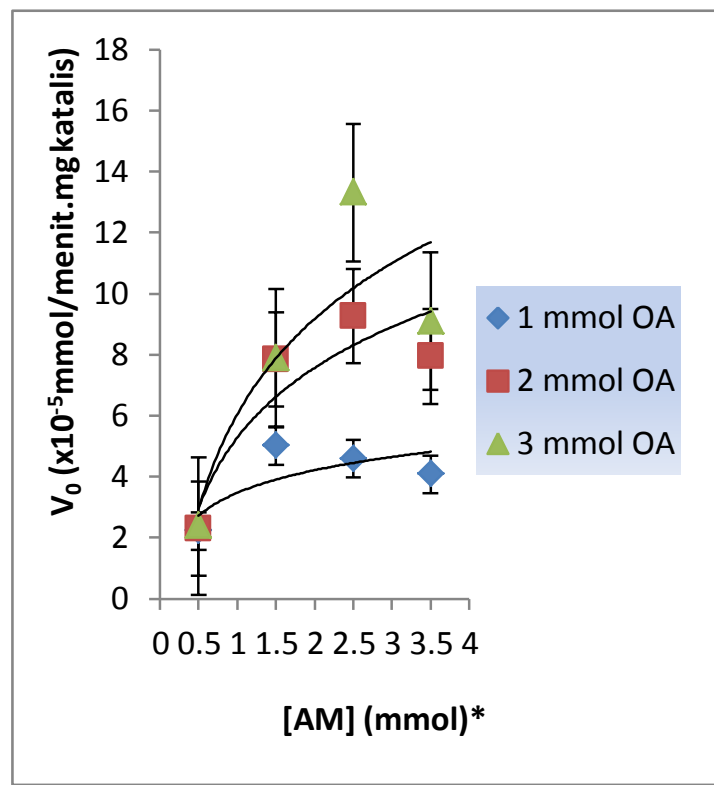

Gambar 4. Grafik Kecepatan awal reaksi esterifikasi pembentukkan oleil miristat sebagai fungsi dari konsentrasi asam miristat (* mmol substrat dalam 2 mL n-heksan)

Grafik Gambar 4. menunjukkan pengaruh variasi asam miristat (oleil alkohol dijaga konstan $1 \mathrm{mmol}, 2 \mathrm{mmol}$, dan 3 mmol) terhadap kecepatan awal reaksi pembentukan oleil miristat. Dari grafik di atas tampak bahwa terjadi peningkatan kecepatan reaksi yang signifikan dari konsentrasi asam miristat 0,5 mmol ke 1,5 mmol, pada konsentrasi 2,5 mmol dan 3,5 mmol peningkatan kecepatan reaksi semakin rendah atau dapat dikatakan kecepatan reaksi mendekati optimum, hal ini terjadi karena pada titik ini enzim mengalami 
penjenuhan oleh substrat. Pola seperti ini mengikuti model kinetika MichaelisMenten.

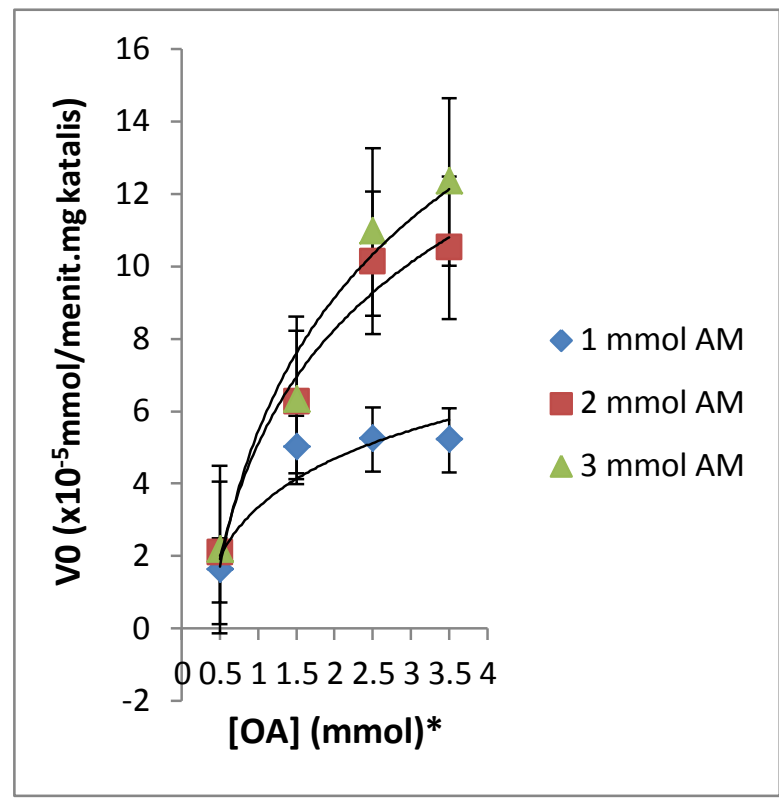

Gambar 5. Grafik Kecepatan awal reaksi esterifikasi pembentukan oleil miristat sebagai fungsi dari konsentrasi oleil alkohol (* mmol substrat dalam 2 mL pelarut n-heksan)

Grafik Gambar 5. menunjukkan pengaruh variasi oleil alkohol (asam miristat dijaga konstan $1 \mathrm{mmol}, 2 \mathrm{mmol}$, dan 3 mmol) terhadap kecepatan awal reaksi pembentukan oleil miristat. Dari grafik di atas, untuk konsentrasi asam miristat 1 mmol tampak bahwa terjadi peningkatan kecepatan reaksi yang signifikan dari konsentrasi oleil alkohol 0,5 mmol ke 1,5 mmol, pada konsentrasi oleil alkohol 2,5 mmol dan 3,5 mmol peningkatan kecepatan reaksi semakin rendah. Untuk konsentrasi asam miristat 2 mmol dan 3 mmol, tampak bahwa terjadi peningkatan kecepatan reaksi yang besar dari konsentrasi asam miristat $0,5 \mathrm{mmol}$ ke konsentrasi 2,5 mmol dan pada konsentrasi asam miristat 3,5 mmol kecepatan reaksi semakin rendah. Pola seperti ini mengikuti model kinetika MichaelisMenten.

Pemetaan kebalikan-ganda atau Lineweaver-Burk dari kecepatan awal pembentukan oleil miristat reaksi versus kebalikan dari variasi konsentrasi asam miristat dan kebalikan dari variasi konsentrasi oleil alkohol menunjukkan pasangan garis yang paralel seperti yang tampak pada Gambar 6 dan 7. Hal tersebut mengindikasikan bahwa pembentukan oleil miristat dari asam miristat dan oleil alkohol dengan menggunakan enzim lipase mengikuti mekanisme Bi-Bi Ping Pong (Awang, dkk., 2003)

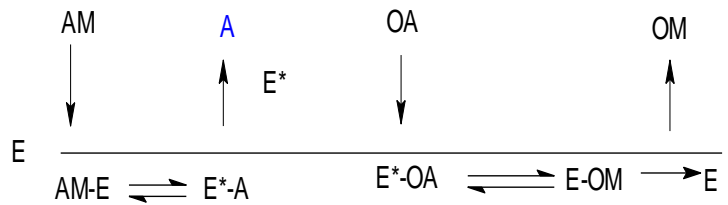

Gambar 6. Mekanisme reaksi esterifikasi pembentukan oleil miristat (wax ester)

Ket:

$\mathrm{E}=$ enzim,

$\mathrm{AM}=$ asam miristat,

AO-E $=$ Kompleks enzimasam miristat,

$\mathrm{E}^{*} \quad=$ enzim modifikasi,

$\mathrm{A}=$ air,

$\mathrm{E}^{*}-\mathrm{A}=$ kompleks enzim modifikasi-air,

$\mathrm{E}^{*}-\mathrm{OA}=$ kompleks enzim modifikasi-oleil alkohol,

E-OM=kompleks enzimoleil miristat (wax ester),

$\mathrm{OM}=$ oleil miristat $($ wax estar)

Slope (a) dan intersep (b) dari tiga garis paralel pada Gambar 7 dirataratakan, sehingga diperoleh persamaan garis linear $\mathrm{y}=17833,6667 \mathrm{x}+6953$. Dari persamaan ini dapat ditentukan nilai $\mathrm{Km}$ dan Vmaks oleil alkohol berturut-turut 
adalah 2,5649 mmol dan $14,3823 \times 10^{-5}$ $\mathrm{mmol} / \mathrm{menit}$.mg katalis.

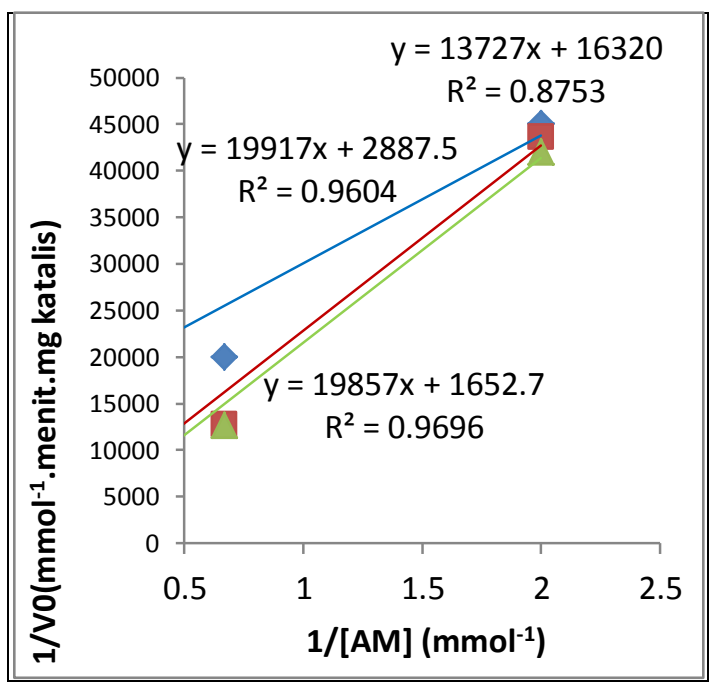

Gambar 7. Plot Lineweaver-Burk dari esterifikasi pembentukan oleil miristat sebagai fungsi dari asam miristat

Slope (a) dan intersep (b) dari tiga garis paralel pada Gambar 8 dirataratakan, sehingga diperoleh persamaan garis linear $\mathrm{y}=24066,6667 \mathrm{x}+3421,2333$. Dari persamaan ini dapat ditentukan nilai $\mathrm{Km}$ dan Vmaks oleil alkohol berturutturut adalah 7,0345 mmol dan $29,2292 \times 10^{-5} \mathrm{mmol} / \mathrm{menit} . \mathrm{mg}$ katalis.

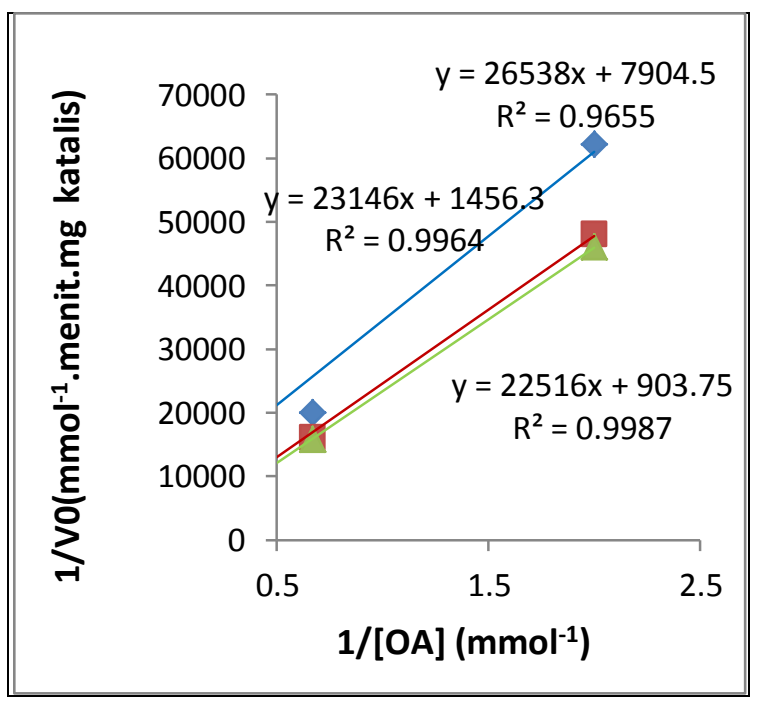

Gambar 8. Plot Lineweaver-Burk dari esterifikasi pembentukan oleil miristat sebagai fungsi dari oleil alkohol

Dari persamaan linear yang diperoleh dari hasil plot lineweaver-Burk dapat ditentukan nilai $\mathrm{Km}$ dan Vmaks untuk masing-masing asam miristat dan oleil alkohol. Nilai Km dan Vmaks dari asam miristat dan oleil alkohol dapat dilihat pada Tabel 5.

Tabel 5. Nilai Km dan Vmaks dari asam miristat dan oleil alkohol

\begin{tabular}{|c|c|c|}
\hline Substrat & $\begin{array}{c}\mathrm{Km} \\
(\mathrm{mmol})\end{array}$ & $\begin{array}{c}\text { Vmaks } \\
(\mathrm{mmol} / \mathrm{menit} . \mathrm{mg} \\
\text { katalis })\end{array}$ \\
\hline $\begin{array}{c}\text { Asam } \\
\text { miristat }\end{array}$ & 2,5649 & $14,3823 \times 10^{-5}$ \\
\hline $\begin{array}{c}\text { Oleil } \\
\text { alkohol }\end{array}$ & $\begin{array}{c}7,0345 \\
\mathrm{mmol}\end{array}$ & $29,2292 \times 10^{-5}$ \\
\hline
\end{tabular}

Nilai Km berbanding lurus dengan Vmaks. Dari hasil penelitian diperoleh nilai $\mathrm{Km}$ oleil alkohol lebih besar dari $\mathrm{Km}$ asam miristat. Nilai $\mathrm{Km}$ menyatakan jumlah konsentrasi substrat dimana kecepatan reaksi adalah $1 / 2$ dari maksimal. Apabila suatu enzim memilki $\mathrm{Km}$ kecil maka akan mencapai efisiensi katalitik yang maksimal pada konsentrasi substrat yang rendah atau dapat dikatakan bahwa afinitas enzim besar (Hairuddin, 2008). Dari hasil penelitian dapat disimpulkan bahwa afinitas asam miristat dengan enzim bebas lebih besar dibanding dengan oleil alkohol dengan asil-enzim. Enzim lipase memiliki sifat spesifisitas relatif, karena dapat bereaksi dengan lebih dari satu substrat, dengan kecepatan yang berbeda (Simanjuntak. 2006).

\section{KESIMPULAN}

Dari hasil penelitian dapat disimpulkan bahwa kinetika reaksi 
esterifikasi dari asam miristat dengan oleil alkohol pembentukan wax ester yang dikatalis oleh enzim lipase mengikuti model kinetika MichaelisMenten. Enzim Lipase memiliki sifat spesifitas relatif, karena dapat bereaksi dengan lebih dari satu substrat. Dari penelitian pada pembentukan wax ester (oleil miristat), nilai $\mathrm{Km}$ oleil alkohol lebih besar dari $\mathrm{Km}$ asam miristat, artinya afinitas asam miristat dengan enzim bebas lebih besar dibanding dengan oleil alkohol dengan asil-enzim.

\section{UCAPAN TERIMKASIH}

Terimakasih penulis ucapkan kepada Neneng Khaerunisya atas kontribusi dalam penelitian ini

\section{DAFTAR PUSTAKA}

Awang, R., M. Basri, S. Ahmad, B. Salleh, 2003, Lipase-catalyzed Esterification of Palm-based 9,10-dihydroxystearic Acid and 1-octanol in Nexane-Kinetic Study, Biotecnology Letters. 26:11-14.

Chen, J. P, and Wang, J. B. 1997, Wax ester synthesis by lipasecatalyzed esterification with fungal cells immobilized on cellulose biomass support particles. Enz. Microb. Technol. 20, 615-622.

Gunawan, E.R dan Suhendra, D. 2008, Synthesis of Wax ester From Palm Kernel Oil Catalyzed by Lipase, Jurnal Matematika dan Sains, Vol. 13 No. 3, 76-83.

Hallberg, M. L., D. Wang, and M. Harrod, 1999, Enzymatic Synthesis of Wax Esters from Rapeseed Fatty Acid Methyl Esters and Fatty Alcohol, J. Am. Oil Chem. Soc., 76:2, 183-187.
Hairuddin, 2008. Sifat Enzim: Spesifitas Enzim.darihttp://klinikdokterhai rrudin.blogspot.com/2008/09/sif at-enzim-spesifisitasenzim.html\#!/2008/09/sifatenzim-spesifisitas-enzim.html pada tanggal 6 November 2001, pukul 13.00 Wita.

Hilyati, Wuryaningsih dan Irawan, Yan. 2003. Sintesa Ester Asam Lemak dengan Alcohol Sekunder Sebagai Emollient, Pusat Penelitian Kimia LIPI. P: C-127-C135.

Khopkar, S.M., 2008, Konsep Dasar Kimia Analitik, Jakarta: UI Press.

Morie, Indigo, 2008. Titrasi Asam Basa. Didownload dari http://belajarkimia.com/2008/04 /titrasi-asam-basa/ pada tanggal 28 Oktober 2011, pukul 08.00 Wita.

Poedjiadi, Anna dan Supriyanti, Titin, 2007. Dasar-Dasar Biokimia. Universitas Indonesia Press: Jakarta

Rahmatullaili, F., 2011, Sintesis Wax Ester dari Asam Lemak Oleat dengan Oleyl Alkohol Secara Enzimatis, Skripsi Program Studi Kimia Fakultas MIPA UNRAM

Ruslin, F., 2011, Sintesis Wax Ester dari Asam Miristat dengan oleil Alkohol secara Enzimatis sebagai Bahan Baku Kosmetik, Skripsi, Program Studi Kimia Fakultas MIPA UNRAM.

Simanjuntak. 2006. Diktat Kuliah Biokimia Pengantar Kinetika Enzim. Didownload dari http://repository.usu.ac.id/bitstr eam/123456789/3605/1/060025 26.pdf pada tanggal 30 April, pukul 18.30 Wita. 